\title{
A comparative study of maternal and perinatal outcome in patients with and without HELLP syndrome
}

\author{
M. Sujatha*, M. Meena
}

Department of Obstetrics and Gynecology, Tirunelveli Medical College Hospital, Tirunelveli, Tamilnadu, India

Received: 27 October 2016

Revised: 25 November 2016

Accepted: 29 November 2016

\section{*Correspondence:}

Dr. M. Sujatha,

E-mail: sujathaalageshan@gmail.com

Copyright: () the author(s), publisher and licensee Medip Academy. This is an open-access article distributed under the terms of the Creative Commons Attribution Non-Commercial License, which permits unrestricted non-commercial use, distribution, and reproduction in any medium, provided the original work is properly cited.

\section{ABSTRACT}

Background: A prospective study of feto maternal outcome in severe preeclampsia and eclampsia with and without HELLP syndrome. The aim of the study was to compare the feto maternal outcome in pregnant woman with severe preeclampsia and eclampsia with HELLP syndrome and without HELLP syndrome.

Methods: 100 cases of severe preeclampsia/eclampsia with and without HELLP syndrome were analyzed in Government Tirunelveli Medical College Hospital. Maternal morbidity and mortality were compared between the two groups.

Results: $83.7 \%$ of cases among HELLP group had normal maternal outcome. $11.6 \%$ maternal mortality among the HELLP syndrome group. 54.5\% babies among HELLP group had abnormal perinatal outcome and 24.6\% among non HELLP group.

Conclusions: HELLP syndrome has a significant influence on maternal and perinatal mortality and morbidity.

Keywords: Eclampsia, HELLP syndrome, Maternal and fetal outcome, Severe preeclampsia

\section{INTRODUCTION}

To acronym HELLP syndrome ${ }^{2}$ was wined by Louis Winston in 1982 that clinicians could more early recognize. ${ }^{1,2}$ In the year 1954 Prichard et al described that preeclampsia patient are more prone to develop haemolysis, hepatic dysfunction and low platelet. HELLP syndrome is a serious complication in pregnancy. ${ }^{6,8,11}$ Diagnosis of HELLP syndrome is challenging. ${ }^{10}$

\section{Aim of the study}

A comparative study of fetomaternal outcome in patients with severe pre-eclampsia and eclampsia with HELLP syndrome and without HELP Syndrome in pregnant women at Government Tirunelveli Medical College Hospital, Tirunelveli.

\section{METHODS}

Analysis of 100 cases of severe preeclampsia/eclampsia with HELLP syndrome and without HELLP syndrome during the year 2015 in Tirunelveli Medical College Hospital, Tirunelveli.

The patients were divided into 2 groups:

- Severe Preeclampsia/Eclampsia with HELLP syndrome (HELLP Group)

- Severe Preeclampsia/Eclampsia without HELLP syndrome(NON-HELLP Group)

Both groups were in admitted in labour ward kept under careful monitoring. Investigations like CBC, RFT, LFT, BT, CT, PT, aPTT, Fibrinogen were sent.

General Nursing Care, Electrolyte balance, monitoring 
urine output were done.

\section{Medical management}

- Antihypertensive drugs

- Prophylactic Mgso4 for severe preeclampsia

\section{Obstetric management}

- Termination of pregnancy - based on Bishop score

- If Bishop Score is favourable, labour will be accelerated with oxytocin drip and ARM.

- If Bishop Score is unfavourable induction of labour with prostaglandins will be done.

- Caesarian section will be done for obstetric indications.

The women and new-born will be monitored for 1 week in the post-partum period. Outcome was measured in terms of perinatal outcome and maternal outcome. Present clinical study will be carried on 100 cases of severe preeclampsia and eclampsia above 28 weeks of gestational age with and without HELLP syndrome admitted in Medical college Hospital, Tirunelveli for a period of 6 months from Feb 2015 to July 2015. These patients were followed up prospectively till delivery.

Sample size: 100 cases

\section{Inclusion criteria}

All pregnant women above 28 weeks of gestational age with severe preeclampsia/eclampsia with one or more of the following:

- Haemolysis detected by either Peripheral smear or Elevated Indirect bilirubin $(>1.2 \mathrm{mg} \%)$ or Elevated LDH levels $(>600 \mathrm{u} / \mathrm{L})$

- $\quad$ Elevated liver enzymes $(\mathrm{AST}>70 \mathrm{u} / \mathrm{L})$
- Decreased Platelet count $<100,000 /$ cumm

\section{Exclusion criteria}

- Known case of Hepatic disease

- Known case of hemolytic anaemia's

- Known case of platelet disorders

- Chronic hypertension in pregnancy

- Chronic renal diseases

- Placenta praevia

- Acute fatty liver of pregnancy

\section{Statistical analysis}

The group with HELLP syndrome and the group without HELLP syndrome have been described and the maternal outcome and perinatal outcome were analysed and interpreted as follows. Among the selected 100 mothers, 43 mothers were having HELLP syndrome and the remaining 57 did not have the HELLP syndrome.

In the above description and analysis, the measurable variables were compared between the two by mean and standard deviations. The student $\mathrm{t}$ test was applied to infer the significance of difference between the means. The categorical variables were compared between them by Chi-square test $(\chi 2)$. The statistical analysis and interpretations have been performed by the statistical software IBM SPSS-sdtatistics-20. The P-value less than $0.05(\mathrm{P}<0.05)$ was treated as statistically significant in two tail test.

\section{RESULTS}

\section{Maternal outcome}

The maternal outcome of HELLP group was studied in respect of their Term of delivery, mode of delivery, blood transfusion, complications and condition of mothers.

Table 1: Association between preterm/term delivery with HELLP.

\begin{tabular}{|c|c|c|c|c|c|c|c|c|c|}
\hline \multirow[t]{2}{*}{ Term } & \multicolumn{2}{|c|}{ HELLP } & \multicolumn{2}{|c|}{ Non- HELLP } & \multicolumn{2}{|c|}{ Total } & \multirow[t]{2}{*}{$x^{2}$} & \multirow[t]{2}{*}{ df } & \multirow[t]{2}{*}{ Significance } \\
\hline & No & $\%$ & No & $\%$ & No & $\%$ & & & \\
\hline Pre term & 36 & 83.7 & 37 & 64.9 & 73 & 73.0 & \multirow{3}{*}{4.399} & \multirow{3}{*}{1} & \multirow{3}{*}{$\mathrm{P}<0.05$} \\
\hline Term & 7 & 16.3 & 20 & 35.1 & 27 & 27.0 & & & \\
\hline Total & 43 & 100.0 & 57 & 100.0 & 100 & 100.0 & & & \\
\hline
\end{tabular}

$83.7 \%$ of HELLP group had preterm delivery and $64.9 \%$ of Non-HELLP group had preterm delivery. The HELLP group were statistically associated with pre term delivery $(\mathrm{P}<0.05)$ (Table 1).

Among the HELLP group 55.8\% delivered by LN, $2.3 \%$ by forceps, $41.9 \%$ by LSCS. Among the Non-HELLP group $43.9 \%$ delivered by LN, $3.5 \%$ by forceps, $52.6 \%$ by LSCS. There was no significant association between both groups $\mathrm{P}>0.05$ (Table 2 ).

$84.4 \%$ of HELLP group required blood and blood product transfusion and only $21.1 \%$ of Non-HELLP group required blood transfusion. Hence there was need for blood transfusion in HELLP group which highly significant $(\mathrm{P}<0.001)$ (Table 3$)$. 
Table 4 shows $48.8 \%$ cases among the HELLP group developed complication and $21.1 \%$ cases among the NonHELLP group developed complication. So the complication was strongly associated with HELLP syndrome group (Table 4).

Table 2: Association between mode of delivery with HELLP.

\begin{tabular}{|c|c|c|c|c|c|c|c|c|c|}
\hline \multirow{2}{*}{$\begin{array}{l}\text { Mode of } \\
\text { delivery }\end{array}$} & \multicolumn{2}{|c|}{ HELLP } & \multicolumn{2}{|c|}{ Non- HELLP } & \multicolumn{2}{|c|}{ Total } & \multirow[t]{2}{*}{$x^{2}$} & \multirow[t]{2}{*}{ df } & \multirow[t]{2}{*}{ Significance } \\
\hline & No & $\%$ & No & $\%$ & No & $\%$ & & & \\
\hline Labour natural & 24 & 55.8 & 25 & 43.9 & 49 & 49.0 & \multirow{4}{*}{3.049} & \multirow{4}{*}{3} & \multirow{4}{*}{$\mathrm{P}>0.05$} \\
\hline Forceps & 1 & 2.3 & 2 & 3.5 & 3 & 3.0 & & & \\
\hline LSCS & 18 & 41.9 & 30 & 52.6 & 48 & 48.2 & & & \\
\hline Total & 43 & 100.0 & 57 & 100.0 & 100 & 100.0 & & & \\
\hline
\end{tabular}

Table 3: Association between blood transfusion with HELLP.

\begin{tabular}{|c|c|c|c|c|c|c|c|c|c|}
\hline \multirow{2}{*}{$\begin{array}{l}\text { Mode of } \\
\text { delivery }\end{array}$} & \multicolumn{2}{|c|}{ HELLP } & \multicolumn{2}{|c|}{ Non- HELLP } & \multicolumn{2}{|l|}{ Total } & \multirow[t]{2}{*}{$x^{2}$} & \multirow[t]{2}{*}{ df } & \multirow[t]{2}{*}{ Significance } \\
\hline & No & $\%$ & No & $\%$ & No & $\%$ & & & \\
\hline Nil & 5 & 11.6 & 45 & 78.9 & 50 & 50.0 & \multirow{4}{*}{49.684} & \multirow{4}{*}{2} & \multirow{4}{*}{$\mathrm{P}<0.001$} \\
\hline PCT & 12 & 27.9 & 9 & 15.8 & 21 & 21.0 & & & \\
\hline PCT/pdt & 26 & 60.5 & 3 & 5.3 & 29 & 29 & & & \\
\hline Total & 43 & 100.0 & 57 & 100.0 & 10 & 100.0 & & & \\
\hline
\end{tabular}

Table 4: Association between complications with HELLP.

\begin{tabular}{|c|c|c|c|c|c|c|c|c|c|}
\hline \multirow[t]{2}{*}{ Complications } & \multicolumn{2}{|c|}{ HELLP } & \multicolumn{2}{|c|}{ Non- HELLP } & \multicolumn{2}{|l|}{ Total } & \multirow[t]{2}{*}{$x^{2}$} & \multirow[t]{2}{*}{ df } & \multirow[t]{2}{*}{ Significance } \\
\hline & No & $\%$ & No & $\%$ & No & $\%$ & & & \\
\hline 22 & 51.2 & 45 & 78.9 & 67 & 67.0 & 22 & \multirow{3}{*}{8.558} & \multirow{3}{*}{1} & \multirow{3}{*}{$\mathrm{P}>0.01$} \\
\hline 21 & 48.8 & 12 & 21.1 & 33 & 33.0 & 21 & & & \\
\hline 43 & 100.0 & 57 & 100.0 & 100 & 100.0 & 43 & & & \\
\hline
\end{tabular}

Table 5: The condition of patient associated with HELLP syndrome.

\begin{tabular}{|c|c|c|c|c|c|c|c|c|c|}
\hline \multirow[t]{2}{*}{ Condition } & \multicolumn{2}{|c|}{ HELLP } & \multicolumn{2}{|c|}{ Non- HELLP } & \multicolumn{2}{|c|}{ Total } & \multirow[t]{2}{*}{$x^{2}$} & \multirow[t]{2}{*}{ df } & \multirow[t]{2}{*}{ Significance } \\
\hline & No & $\%$ & No & $\%$ & No & $\%$ & & & \\
\hline Expired & 5 & 11.6 & 0 & 0.0 & 5 & 5.0 & \multirow{4}{*}{9.977} & \multirow{4}{*}{2} & \multirow{4}{*}{$\mathrm{P}>0.01$} \\
\hline $\begin{array}{l}\text { Normal maternal } \\
\text { outcome }\end{array}$ & 36 & 83.7 & 57 & 100.0 & 93 & 93.0 & & & \\
\hline $\begin{array}{l}\text { Recovered after } \\
\text { haemodialysis }\end{array}$ & 2 & 4.7 & 0 & 0.0 & 2 & 2.0 & & & \\
\hline Total & 43 & 100.0 & 57 & 100.0 & 100 & 100.0 & & & \\
\hline
\end{tabular}

Table 6: Comparison of Perinatal outcome between HELLP and non-HELLP.

\begin{tabular}{|c|c|c|c|c|c|c|c|c|c|}
\hline \multirow[t]{2}{*}{ Term } & \multicolumn{2}{|c|}{ HELLP } & \multicolumn{2}{|c|}{ Non-HELLP } & \multicolumn{2}{|c|}{ Total } & \multirow[t]{2}{*}{$x^{2}$} & \multirow[t]{2}{*}{ df } & \multirow[t]{2}{*}{ Significance } \\
\hline & No & $\%$ & No & $\%$ & No & $\%$ & & & \\
\hline APO & 24 & 54.5 & 14 & 24.6 & 38 & 37.6 & \multirow{3}{*}{9.513} & \multirow{3}{*}{1} & \multirow{3}{*}{$\mathrm{P}<0.001$} \\
\hline NPO & 20 & 45.5 & 43 & 75.4 & 63 & 62.4 & & & \\
\hline Total & 44 & 100.0 & 57 & 100.0 & 101 & 100.0 & & & \\
\hline
\end{tabular}


$83.7 \%$ of case among HELLP group had normal maternal outcome and $100 \%$ case among Non-HELLP group had normal maternal outcome. There was $11.6 \%$ maternal mortality among the HELLP group hence maternal mortality is strongly associated with HELLP syndrome (Table 5).

\section{Perinatal outcome}

The perinatal outcome was studied for Foetus. Among the HELLP group one patient had twins and all 42 mothers had singleton pregnancy. In HELLP group perinatal outcome of forty four babies were analysed.

$54.5 \%$ of babies among HELLP group had an abnormal perinatal outcome and $24.6 \%$ of babies among NonHELLP group. Hence HELLP group is strongly associated with abnormal perinatal outcome. The association is statistically very highly significant $(\mathrm{P}<0.001)$ (Table 6).

Table 7: Comparison of Perinatal outcome between HELLP and non-HELLP.

\begin{tabular}{|c|c|c|c|c|c|c|c|c|c|}
\hline \multirow[t]{2}{*}{ Term } & \multicolumn{2}{|c|}{ HELLP } & \multicolumn{2}{|c|}{ Non- HELLP } & \multicolumn{2}{|c|}{ Total } & \multirow[t]{2}{*}{$x^{2}$} & \multirow[t]{2}{*}{ df } & \multirow[t]{2}{*}{ Significance } \\
\hline & No & $\%$ & No & $\%$ & No & $\%$ & & & \\
\hline IUD & 12 & 27.3 & 4 & 7.0 & 16 & 15.8 & \multirow{3}{*}{7.642} & \multirow{3}{*}{1} & \multirow{3}{*}{$\mathrm{P}<0.01$} \\
\hline Alive & 32 & 72.7 & 53 & 93.0 & 85 & 84.2 & & & \\
\hline Total & 44 & 100.0 & 57 & 100.0 & 101 & 100.0 & & & \\
\hline
\end{tabular}

Table 8: Comparison of birth weight of babies between HELLP and non HELLP.

\begin{tabular}{|c|c|c|c|c|c|c|c|c|}
\hline \multirow{2}{*}{ Term } & \multicolumn{2}{|c|}{ HELLP n=44 } & \multicolumn{2}{|c|}{ Non- HELLP n=57 } & \multirow{2}{*}{$\begin{array}{l}\text { Difference } b / w \\
\text { means }\end{array}$} & \multirow{2}{*}{$' t^{\prime}$} & \multirow{2}{*}{ df } & \multirow{2}{*}{ Significance } \\
\hline & Mean & SD & Mean & SD & & & & \\
\hline $\begin{array}{l}\text { Birth } \\
\text { weight }\end{array}$ & 1.9 & 0.7 & 2.2 & 0.6 & 0.3 & 2.064 & 99 & $\mathrm{P}<0.05$ \\
\hline
\end{tabular}

$72.7 \%$ of babies among HELLP group were alive and 93\% of babies among Non-HELLP group were alive. $27 \%$ were IUD among HELLP group and 7\% among Non-HELLP group. Hence IUD is strongly associated with HELLP syndrome (Table 7).

The mean birth weight of babies belonging to HELLP mothers was $1.9 \pm 0.7 \mathrm{~kg}$. The same of the non-HELLP group mothers was $2.2 \pm 0.6 \mathrm{Kg}$. The different in the mean birth weights between the two groups was statistically significant $(\mathrm{P}<0.05)$ (Table 8$)$.

There were 5 cases of death in HELLP syndrome giving rise to maternal mortality rate of $11.6 \%$. $40 \%$ were primi between 20-24 years of age, and $60 \%$ were multi between 30-35 years of age mostly in severe preeclampsia at 3034 weeks gestation. All cases had significant proteinuria, delivered with 15 hrs of admission. Most common causes of death were abruption and acute renal failure.

\section{DISCUSSION}

A study of 100 cases of HELLP syndrome and nonHELLP syndrome was undertaken during the year 2015 for a period of six months and the result were compared between the maternal and foetal outcome. ${ }^{1,2}$

\section{Maternal outcome}

Though coagulopathy has been mentioned as the most common complication of HELLP Syndrome, in my study all parameters like bleeding time (B.T), Clotting time (C.T), serum fibrinogens were normal. This may be due to non-sensitive parameters to detect DIC. More sensitive parameters like antithrombin IV, factor VIII and D-dimer may be needed to detect DIC.

\section{Maternal mortality}

According to Sibai incidence of maternal mortality is as high as $24 \%$. In my study, there were 5 cases of maternal death giving rise to maternal mortality rate of $11.6 \%$, of these 1 case was due to Pulmonary edema with abruption (20\%), 2 cases were due to abruption and DIC (40\%) and 2 case was due to ARF with DIC (40\%).

\section{Analysis of maternal mortality}

2 cases were in 20-25 years of age and 3 cases were in 30-35 years of age.

Gravida - 2 cases were primigravida and 3 cases were multigravida. 
Blood pressure- $80 \%$ cases belong to severe preeclampsia, $20 \%$ cases belong to Eclampsia. ${ }^{4}$

Gestational age - 4 cases were in 30-34 weeks and 1 case was in 28 weeks.

Proteinuria - All 5 patients had $\geq 2+$ proteinuria.

Platelet count - $40 \%$ cases belong to class-II and $60 \%$ cases belong to class-I HELLP Syndrome.

Liver enzymes - SGOT, SGPT and LDH were significantly elevated in all 5 cases.

Mode of delivery - All delivered by LSCS.

Admission - delivery death interval - 1 day for 3 cases (60\%) and 2 days for 2 case (40\%) In spite of early delivery there was 5 deaths in my study, probably due to late referral. ${ }^{7,8}$

\section{Perinatal outcome}

According to Sibai perinatal mortality is $30-40 \%$ primarily because of prematurity. ${ }^{4}$ There is a significant trend for advanced form of HELLP Syndrome (Class I \& Class II) to appear at earlier gestational age. According to my study perinatal mortality is $54.5 \%$ primarily of prematurity.

\section{Birth weight of the baby}

According to English literature, average weight of the new born is 1524-1898 gms and 30\% were small for gestational age. ${ }^{4}$ According to my study the birth weight of live born babies of HELLP syndrome mothers significantly lesser than the non-HELLP syndrome babies. Mean birth weight of babies of HELLP mothers was $1.9 \pm 0.7 \mathrm{~kg}$. The complications $(48.8 \%)$ were significantly more among the HELLP group than the others. $^{8,11}$ The mortality incidence (11.6\%) was significantly more among HELLP group. ${ }^{4,11}$ The birth weight of live born babies of HELLP syndrome is 1.9 was significantly lesser than the other babies' birth weight. $^{8,11} 27.3 \%$ of IUD and $54.5 \%$ of abnormal perinatal outcome was strongly associated with HELLP syndrome. $^{11}$

\section{ACKNOWLEDGEMENTS}

Authors would like to thank the all patients who have cooperated for the study. My sincere thanks to the Nursing Paramedical staff and CRRI's who treated the patients.
Funding: No funding sources

Conflict of interest: None declared

Ethical approval: The study was approved by the Institutional Ethics Committee

\section{REFERENCES}

1. Pritcharad JA, Weisman R. Haemolysis, Thrombocytopenia and other haematological abnormalities with severe toxemia of pregnancy. $\mathrm{N}$ Engl J Med. 1954;250:89-98.

2. Weinstein L. HELLP Syndrome - a severe consequence of hypertension in pregnancy. Am J Obst Gyn. 1982;142:159-67.

3. Weinstein L. Preeclampsia/eclampsia with HELLP Syndrome. Obst Gyn. 1985;66:657-60.

4. Sibai BM, Mark M. Maternal and perinatal outcome in HELLP syndrome. Am J Obst Gyn. 1986;155:501-9.

5. Sibai BM. The HELLP syndrome much a do about nothing. Am J Obst Gyn. 1990;162:311-6.

6. Sibai BM, Ramadan MK, Usta I, Salama M, Mercer BM, Friedman SA. Maternal Morbidity and Mortality in HELLP syndrome. Am J Obst Gyn. 1993;169(4):1000-6.

7. Sibai BM, Ramadan MK. Pregnancies complicated by HELLP syndrome (hemolysis, elevated liver enzymes, and low platelets): subsequent pregnancy outcome and long-term prognosis. Am J Obst Gyn. 1995;172:125-9.

8. Raval DS, Reid MA. Maternal and neonatal outcome in HELLP syndrome. J Perinatol. 1997;17(4):266-9.

9. Martin JN. Milestones in the quest for best management of patients with HELLP syndrome (microangiopathic hemolytic anemia, hepatic dysfunction, thrombocytopenia). Int J Gynecol Obstet. 2013;121:202-7.

10. Magee LA, Pels A, Helewa M, Rey E, von Dadelszen P. Diagnosis, evaluation, and management of the hypertensive disorders of pregnancy: executive summary. J Obstet Gynaecol Can. 2014;36(5):41638 (SOGC).

11. Chawla S, Marwaha A, Agarwal R. HELLP (or) help: a real challenge. J Obstet Gynaecol India. 2015;65(3):172-5.

Cite this article as: Sujatha M, Meena M. A comparative study of maternal and perinatal outcome in patients with and without HELLP syndrome. Int $\mathbf{J}$ Reprod Contracept Obstet Gynecol 2017;6:49-53. 